\title{
Article
}

\section{Presence of Lactic Acid Bacteria in the Intestinal Tract of the Mediterranean Trout (Salmo macrostigma) in Its Natural Environment}

\author{
Massimo Iorizzo $(\mathbb{D}$, Gianluca Albanese, Bruno Testa $* \mathbb{0}$, Mario Ianiro, Francesco Letizia, Mariantonietta Succi, \\ Patrizio Tremonte, Mariasilvia D’Andrea (D), Nicolaia Iaffaldano (i) and Raffaele Coppola (D)
}

\section{check for} updates

Citation: Iorizzo, M.; Albanese, G.; Testa, B.; Ianiro, M.; Letizia, F.; Succi, M.; Tremonte, P.; D'Andrea, M.; Iaffaldano, N.; Coppola, R.

Presence of Lactic Acid Bacteria in the Intestinal Tract of the Mediterranean Trout (Salmo macrostigma) in Its Natural Environment. Life 2021, 11, 667. https://doi.org/10.3390/ life11070667

Academic Editor: Peter Deines

Received: 27 April 2021

Accepted: 5 July 2021

Published: 7 July 2021

Publisher's Note: MDPI stays neutral with regard to jurisdictional claims in published maps and institutional affiliations.

Copyright: (c) 2021 by the authors. Licensee MDPI, Basel, Switzerland. This article is an open access article distributed under the terms and conditions of the Creative Commons Attribution (CC BY) license (https:// creativecommons.org/licenses/by/ $4.0 /)$.
Department of Agriculture, Environmental and Food Sciences, University of Molise, Via De Sanctis, 86100 Campobasso, Italy; iorizzo@unimol.it (M.I.); g.albanese@studenti.unimol.it (G.A.); m.ianiro@studenti.unimol.it (M.I.); f.letizia@studenti.unimol.it (F.L.); succi@unimol.it (M.S.); tremonte@unimol.it (P.T.); dandrea@unimol.it (M.D.); nicolaia@unimol.it (N.I.); coppola@unimol.it (R.C.)

* Correspondence: bruno.testa@unimol.it

\begin{abstract}
Knowledge of the composition of the gut microbiota in freshwater fish living in their natural habitat has taxonomic and ecological importance. Few reports have been produced on the composition of the gut microbiota and on the presence of LAB in the intestines of freshwater fish that inhabit river environments. In this study, we investigated the LAB community that was present in the gastrointestinal tract (GIT) of Mediterranean trout (Salmo macrostigma) that colonized the Biferno and Volturno rivers of the Molise region (Italy). The partial 16S rRNA gene sequences of these strains were determined for the species-level taxonomic placement. The phylogenetic analysis revealed that the isolated LABs belonged to seven genera (Carnobacterium, Enterococcus, Lactobacillus, Lactiplantibacillus, Vagococcus, Lactococcus, and Weissella). The study of the enzymatic activities showed that these LABs could contribute to the breakdown of polysaccharides, proteins, and lipids. In future studies, a greater understanding of how the LABs act against pathogens and trigger the fish immune response may provide practical means to engineer the indigenous fish microbiome and enhance disease control and fish health.
\end{abstract}

Keywords: lactic acid bacteria; gut microbiota; Mediterranean trout; river environment

\section{Introduction}

The intestinal tracts of fishes contain a complex and dynamic community of microorganisms [1,2]. Among them, the lactic acid bacteria (LAB) play an important role due to some of their properties: production of antimicrobial substances and improved disease resistance, greater antioxidative stress tolerance, immune response stimulation, and increase in the availability of nutrients [3-5]. LABs were among the first living organisms on Earth; they appeared about three billion years ago in the transition period from anaerobiosis to aerobiosis. They seem to have adapted well to both anaerobic and aerobic life conditions since they bear all the necessary proteins for respiration and several enzymes involved in fermentative pathways [6]. Several species of LABs belonging to the Lactobacillus, Lactococcus, Leuconostoc, Enterococcus, Streptococcus, Carnobacterium, Pediococcus, and Weissella genera have adapted to grow under very different environmental conditions and are important representatives of the gut microbiota of both freshwater and marine fish [7]. In recent decades, numerous studies have shown that different intrinsic and extrinsic factors affect the level, composition, and/or diversity of the fish gut microbiota: life stage, trophic level, diet, seasonality, habitat, stress, sex, and phylogeny [8-10]. LAB's diversity was particularly studied in freshwater fish, but few reports have been produced on the composition of the gut microbiota and on the presence of LABs in the intestines of freshwater fish that inhabit river environments [11-14]. 
Knowledge of the composition of the gut microbiota in freshwater fish living in their natural habitat has taxonomic and ecological importance. In particular, the study of the gut microbiome in threatened wildlife species has enormous potential to improve conservation efforts and to gain insights into the host-microbe coevolution. The interaction of animals with their respective symbiotic microorganisms can provide important tools for the management of various issues related to the protection of endangered animal species [15]. Salmo macrostigma is an endemic freshwater trout species of the Mediterranean area (Figure 1). This salmonid is protected by the Habitats Directive 92/43/EEC and is considered a "vulnerable species" in Europe and "critically endangered" in Italy [16]. The diet of the Mediterranean trout consists mainly of macrozoobenthos, larvae and adult insects, and to a lesser extent, vegetable elements, crustaceans, and mollusks. Macroinvertebrates and fry and small fish, as well as being food competitors, also represent a valid source of nourishment in the vital stages of the Mediterranean trout. The water temperature in this species' thermal niches is between 7 and $15^{\circ} \mathrm{C}$, which is the optimal survival range for this cold stenothermal fish species [17-20]. In this study, we investigated the LAB community present in the gastrointestinal tract (GIT) of the Mediterranean trout (Salmo macrostigma) that inhabits river environments. At present no similar studies are available on this freshwater fish species.

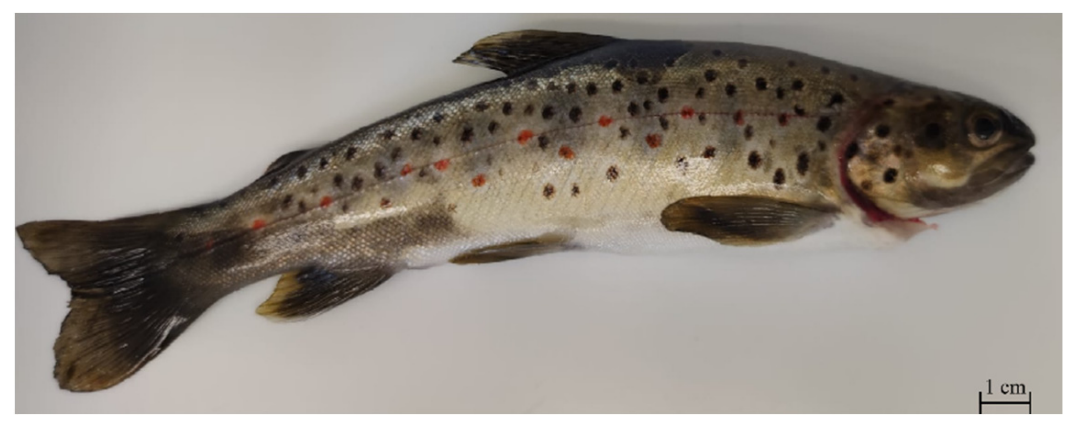

Figure 1. Adult specimen of Mediterranean trout.

\section{Materials and Methods}

\subsection{Lactic Acid Bacteria (LAB) Isolation}

A total of 18 adult specimens of Mediterranean trout that accidentally died in the fish traps used in the scientific activities of the LIFE Nat. Sal. Mo Project (LIFE17 NAT/IT/000547) was collected. The fish were taken from 7 different study sites on the Biferno (4 sites) and Volturno (3 sites) rivers (Molise region, Italy) between November and January during the daily inspection of the fish traps and immediately transported in portable refrigerators $\left(2-8{ }^{\circ} \mathrm{C}\right)$ to the microbiology laboratory. The exterior of the fish was wiped clean with $70 \%$ ethanol, the abdomen opened at the ventral midline, and the whole intestine was aseptically removed from the abdominal cavity and separated into the proximal (pyloric ceca, PC) and midgut (MG) sections (Figure 2).

Once the specimens were longitudinally opened, the MG sections were rinsed using $3 \% \mathrm{NaCl}$ to remove non-adherent (allochthonous) bacteria and digesta. Later, the PC and MG matrices were homogenized together in sterile physiological water $(0.9 \% \mathrm{NaCl})$ and serial decimal dilutions were obtained. The bacterial colonies were isolated by plating serial decimal dilutions on MRS and M17 media (Oxoid, Milan, Italy) that were supplemented with cycloheximide $(40 \mathrm{mg} / \mathrm{L})$. Plates were incubated at $30{ }^{\circ} \mathrm{C}$ under anaerobic conditions using an anaerobic system (AnaeroGen, Oxoid, Milan, Italy). After 48-72 h, approximately $5 \%$ of the colonies were isolated and purified from culture plates by streaking them on the respective culture media. The bacterial colonies were randomly selected according to morphological differences (colony size and shape). 


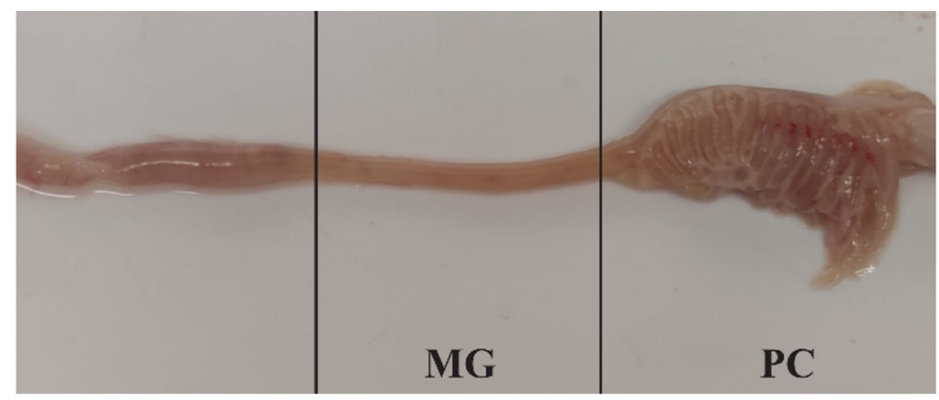

Figure 2. The intestinal tract of an adult Mediterranean trout. Pyloric ceca (PC) and midgut (MG) sections.

\subsection{Phenotypic and Biochemical Characterization}

Prior to genotypic identification, presumptive LABs isolates were examined for their Gram reactions and catalase activity. The Gram reactions were performed by dissolving a loop full of freshly grown colony material in a drop of 3\% $\mathrm{KOH}$ (Sigma-Aldrich; St. Louis, $\mathrm{MO}, \mathrm{USA}$ ) on a microscope slide. Like the Gram stain reaction, the $\mathrm{KOH}$ test is based on differences in the chemistry of the bacterial cell wall. In the presence of potassium hydroxide, Gram-negative cell walls are broken down. $\mathrm{KOH}$ easily dissolves the thin layer of peptidoglycan of the cell walls of Gram-negative bacteria. On the other hand, Gram-positive bacteria are not affected by $\mathrm{KOH}$ because they have a thicker peptidoglycan layer in the cell wall. The isolates, which did not give a viscid product, were selected since LAB are known as Gram-positive cells [21].

The catalase activity was determined by adding a drop of hydrogen peroxide $\left(\mathrm{H}_{2} \mathrm{O}_{2}\right.$; Sigma-Aldrich) solution (5\%) to a small quantity of colony mass on a glass slide. The catalase test differentiates bacteria that produce a catalase enzyme that can degrade $\mathrm{H}_{2} \mathrm{O}_{2}$ in water and free oxygen. The production of oxygen bubbles can be observed.

After genotypic identification, the enzyme activity of the LABs was determined using an API-ZYM system (bioMérieux SA, Marcy l'Etoile, France) according to the manufacturer's instructions.

\subsection{Genotypic Identification}

Genomic DNA from pure cultures of putative LABs was extracted using a Bacterial Genomic DNA Isolation Kit (Norgen Biotek, Thorold, ON, Canada) according to the manufacturer's instructions. The $16 \mathrm{~S}$ rRNA gene fragments were amplified using the 27F and $1492 \mathrm{R}$ primer pair [22].

The polymerase chain reaction (PCR) mixture contained $10 \mu \mathrm{L} 2 \times$ PCR master mix (Norgen Biotek), $0.5 \mu \mathrm{L}$ of each primer $(2.5 \mu \mathrm{M}), 7 \mu \mathrm{L}$ Milli-Q water, and $2 \mu \mathrm{L}$ template DNA. In the negative control for the PCR reactions, Milli-Q water was used instead of DNA. The PCR reactions were performed with a Mastercycler Nexus PCR thermal cycler (Eppendorf, Hamburg, Germany). PCR amplifications were achieved using the following program: pre-denaturation at $95^{\circ} \mathrm{C}$ for $10 \mathrm{~min}$, then 30 cycles of denaturation at $95^{\circ} \mathrm{C}$ for $30 \mathrm{~s}$, annealing for $1 \mathrm{~min}$, and extension at $72{ }^{\circ} \mathrm{C}$ for $1.5 \mathrm{~min}$. The last cycle was followed by a 7 min extension at $72{ }^{\circ} \mathrm{C}$ [23]. PCR products were analyzed using electrophoresis on a $1.0 \%(w / v)$ agarose gel in a $1 \times$ Tris-Borate-EDTA (TBE) buffer.

The bands were visualized under a UV transilluminator (Bio-Rad, Hercules, CA, USA) and the sizes were estimated by comparison against $1 \mathrm{~kb}$ DNA ladder (Norgen Biotek).

PCR products were purified using a QIAquick PCR purification kit (QIAGEN GmbH, Hilden, Germany) and sent to a commercial facility for sequencing (Eurofins MWG Biotech Company, Ebersberg, Germany). The 16S rRNA sequences were examined using the Basic Local Alignment Search Tool (BLAST) [24] program and were compared with known reference databases in the National Center for Biotechnology Information (NCBI) for taxonomic placement [25]. 


\section{Results}

\subsection{LAB Species Diversity}

In total, sixty-one Gram-positive and catalase-negative bacterial strains were presumptively considered LABs. The partial $16 \mathrm{~S}$ rRNA gene sequences of these strains were determined for taxonomic placement. The BLASTN algorithm was applied to the GenBank database to identify sequences (http:/ / www.ncbi.nlm.nih.gov/BLAST/ (accessed on 26 June 2021). The sequence of the closest related type strain was compared with the respective sequence of our collected strains.

Sequence matches that showed high identity scores ( $98 \%$ and above) were considered acceptable for taxonomic placement at the species level [26].

According to the 16S rRNA gene sequences, all isolated strains and their related type strains were used to construct a phylogenetic tree (Figure 3) using the MEGA X program [27] via the maximum likelihood method and the Hasegawa-Kishino-Yano model [28]. The partial 16S rRNA gene sequences obtained during the identification of LAB isolates were submitted to the GenBank database. Table S1 (Supplementary Material) shows the list of isolates LABs with the corresponding GenBank accession numbers and the taxonomic references.

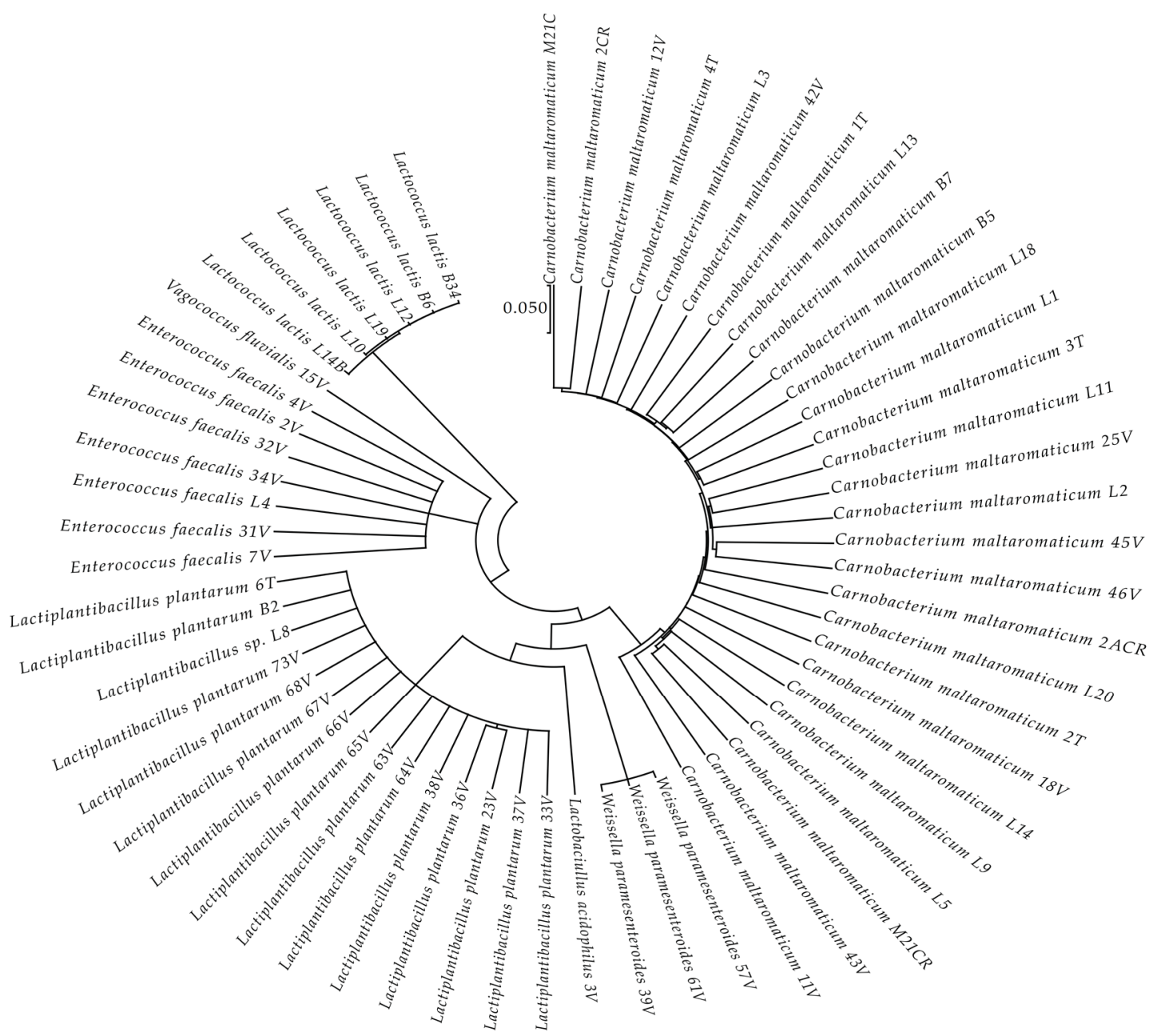

Figure 3. Results of the phylogenetic analysis of $16 \mathrm{~S}$ rRNA gene sequences of the 61 LABs isolates compared with the sequences of type strains from the National Centre for Biotechnology Information (NCBI). The analysis was conducted with the MEGA X program [27] using the maximum likelihood method and the Hasegawa-Kishino-Yano model [28]. The scale bar represents a $5 \%$ nucleotide sequence difference. 
The phylogenetic analysis revealed that the 61 strains belonged to 7 genera (Carnobacterium, Enterococcus, Lactobacillus, Lactiplantibacillus, Vagococcus, Lactococcus, and Weissella). The majority of the LAB isolates were identified as Carnobacterium maltoaromaticum (28 strains), Lactiplantibacillus plantarum (14 strains), Enterococcus faecalis (7 strains), Lactococcus lactis (6 strains), and Weisella paramesenteroides (3 strains). A minority of LABs were identified as Lactobacillus acidophilus and Vagococcus fluvialis (1 strain each). It was not possible to determine whether the L8 strain belonged to the species L $p$. plantarum or Lp. pensosus. Our results confirmed that the definition of the phylogenetic distances and sometimes even the differentiation using 16S RNA sequencing was not feasible for $L p$. plantarum and Lp. pentosus because of the high similarity. In fact, these two species belong to the same phylogenetic group (Lp. plantarum group) $[29,30]$. In Figure 4, the percentage distribution of LABs species is shown. C. maltoaromaticum was widely found in 12 trout specimens (percentage frequency $66.67 \%$ ), Lp. plantarum was detected in 7 trout specimens $(44.44 \%)$, while Lc. lactis and E. faecalis were detected in $27.78 \%$ of the trout specimens. Table 1 shows the presence and frequency (\%) of every LAB species in the intestinal tract of the 18 trout specimens.

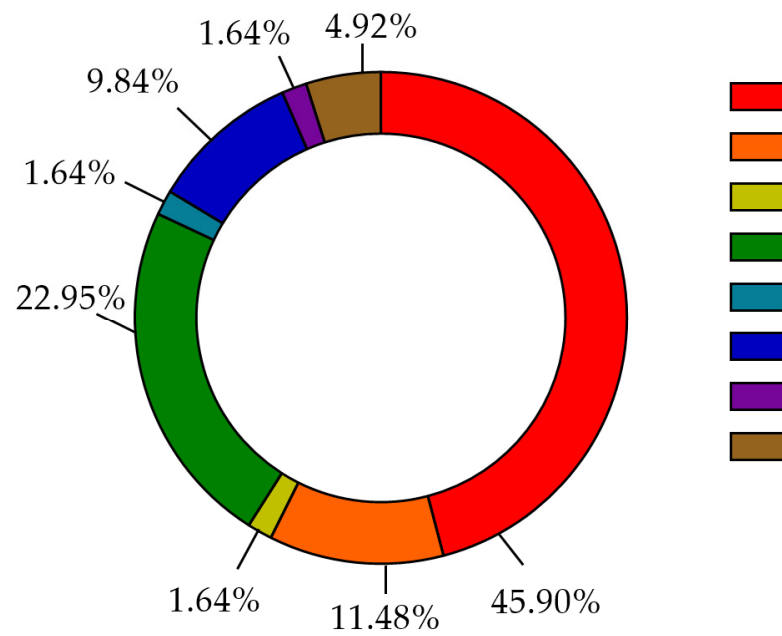

Carnobacterium maltaromaticum Enterococcus faecalis Lactiplantibacillus sp.

Lactiplantibacillus plantarum Lactobacillus acidophilus

Lactococcus lactis

Vagococcus fluvialis

Weissella paramesenteroides

Figure 4. Donut chart showing the percentage distribution of the LAB species (61 strains) that were isolated from the intestinal tracts of the Mediterranean trout.

Table 1. Occurrence and frequency of LAB species in the digestive tract of Mediterranean trout specimens.

\begin{tabular}{ccccc}
\hline LAB Species & $\begin{array}{c}\text { Number of } \\
\text { Strain Isolates }\end{array}$ & $\begin{array}{c}\text { Host Trout } \\
\text { Specimens }\end{array}$ & $\begin{array}{c}\text { Total Trout } \\
\text { Specimens }\end{array}$ & $\begin{array}{c}\text { Frequency } \\
\text { (\%) }\end{array}$ \\
\hline Carnobacterium maltaromaticum & 28 & 12 & 18 & 66.7 \\
Lactiplantibacillus plantarum & 14 & 8 & 18 & 44.4 \\
Lactococcus lactis & 6 & 5 & 18 & 27.8 \\
Enterococcus faecalis & 7 & 4 & 18 & 5.5 \\
Lactobacillus acidophilus & 1 & 1 & 18 & 5.5 \\
Lactiplantibacillus sp. & 1 & 1 & 18 & 5.5 \\
Vagococcus fluvialis & 1 & 1 & 18 & 5.5 \\
Weisella paramesenteroides & 3 & & & \\
\hline
\end{tabular}

\subsection{Biochemical Characterization}

The enzymatic activities assayed using the API-ZYM system are presented in Table 2. All LAB isolates showed no activities for the enzymes $\beta$-glucuronidase, $\alpha$-mannosidase, and trypsin. The acid phosphatase, lipase, and $\alpha$-chymotrypsin enzymes were not detected in the L $p$. plantarum strains, which instead exhibited the following enzymatic activities: alkaline phosphatase, $\beta$-galactosidase, $\alpha$-glucosidase, $\beta$-glucosidase, and $N$-acetyl- $\beta$ glucosaminidase. All the strains belonging to C. maltaromaticum species showed acid phos- 
phatase, cystine arylamidase, leucine arylamidase, valine arylamidase, naphthol-AS-BIphosphohydrolase, and $\mathrm{N}$-acetyl- $\beta$-glucosaminidase activities. Meanwhile, $\alpha$-mannosidase, $\alpha$-fucosidase, $\alpha$-chymotrypsin, and lipase activities were not detected in C. maltaromaticum species. Lipase and $\alpha$-chymotrypsin activities were detected only in Lc. lactis strains.

Table 2. Enzymatic profiles of 61 isolated LAB strains using the API-ZYM system ( $\bullet$ positive, $\bullet$ negative, $\bullet$ variable). The number of isolated strains belonging to the different species is shown in parentheses, and for each enzymatic activity, the sparkline chart indicates the percentage of positive strains.

\begin{tabular}{|c|c|c|c|c|c|c|c|c|c|}
\hline $\begin{array}{l}\text { Enzyme } \\
\text { Assayed }\end{array}$ & C. maltoaromaticum & E. faecalis & Lactiplantibacillus sp. & Lp. plantarum & L. acidophilus & Lc. lactis & V. fluvialis & W. paramesenteroides & $\begin{array}{l}\text { Sparkline } \\
\text { Chart (\%) }\end{array}$ \\
\hline & (28) & (7) & (1) & (14) & (1) & (6) & (1) & (3) & \\
\hline $\begin{array}{c}\text { Alkaline } \\
\text { phosphatase }\end{array}$ & $\bullet$ & - & - & - & $\bullet$ & $\bullet$ & $\bullet$ & - & 1_u_u_ \\
\hline Esterase (C4) & $\bullet$ & $\bullet$ & $\bullet$ & 0 & $\bullet$ & $\bullet$ & $\bullet$ & $\bullet$ & 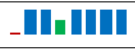 \\
\hline Esterase lipase (C8) & - & - & $\bullet$ & 0 & - & - & - & - & U1._DI \\
\hline Lipase (C14) & $\bullet$ & $\bullet$ & $\bullet$ & $\bullet$ & $\bullet$ & 0 & $\bullet$ & $\bullet$ & $------n--$ \\
\hline $\begin{array}{c}\text { Leucine } \\
\text { arylamidase }\end{array}$ & $\bullet$ & - & $\bullet$ & 0 & $\bullet$ & $\bullet$ & $\bullet$ & $\bullet$ & II_n_ \\
\hline Valine arylamidase & $\bullet$ & $\bullet$ & - & - & $\bullet$ & $\bullet$ & $\bullet$ & $\bullet$ & IIII_-__-_ \\
\hline Cystine arylamidase & $\bullet$ & $\bullet$ & $\bullet$ & $\bullet$ & $\bullet$ & $\bullet$ & $\bullet$ & $\bullet$ & $\mathbf{I}_{---} \mathbf{1}_{--}$ \\
\hline Trypsin & $\bullet$ & $\bullet$ & $\bullet$ & $\bullet$ & $\bullet$ & $\bullet$ & $\bullet$ & $\bullet$ & --------- \\
\hline$\alpha$-chymotrypsin & $\bullet$ & $\bullet$ & $\bullet$ & - & $\bullet$ & - & $\bullet$ & - & _-_-_-_ \\
\hline Acid phosphatase & $\bullet$ & - & $\bullet$ & - & $\bullet$ & - & - & - & 1_-_ \\
\hline $\begin{array}{l}\text { Naphthol-AS-BI- } \\
\text { phosphohydrolase }\end{array}$ & $\bullet$ & $\bullet$ & $\bullet$ & - & $\bullet$ & $\bullet$ & $\bullet$ & $\bullet$ & I_- $_{-}$ \\
\hline$\alpha$-galactosidase & - & $\bullet$ & $\bullet$ & - & $\bullet$ & - & $\bullet$ & - & 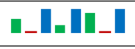 \\
\hline$\beta$-galactosidase & 0 & $\bullet$ & $\bullet$ & $\bullet$ & $\bullet$ & - & $\bullet$ & $\bullet$ & nll11_-_ \\
\hline$\beta$-glucuronidase & $\bullet$ & $\bullet$ & $\bullet$ & $\bullet$ & $\bullet$ & $\bullet$ & $\bullet$ & $\bullet$ & -------- \\
\hline$\alpha$-glucosidase & 0 & $\bullet$ & $\bullet$ & - & $\bullet$ & 0 & $\bullet$ & - & "n_lln_I \\
\hline$\beta$-glucosidase & 0 & $\bullet$ & $\bullet$ & $\bullet$ & $\bullet$ & 0 & $\bullet$ & $\bullet$ & 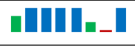 \\
\hline $\begin{array}{c}\mathrm{N} \text {-acetil- } \beta- \\
\text { glucosaminidase }\end{array}$ & - & $\bullet$ & $\bullet$ & $\bullet$ & $\bullet$ & - & $\bullet$ & $\bullet$ & I_-__-_ \\
\hline$\alpha$-mannosidase & $\bullet$ & $\bullet$ & $\bullet$ & $\bullet$ & $\bullet$ & $\bullet$ & $\bullet$ & $\bullet$ & -------- \\
\hline$\alpha$-fucosidase & 0 & $\bullet$ & $\bullet$ & 0 & $\bullet$ & $\bullet$ & $\bullet$ & $\bullet$ & $\left\|_{--}\right\|_{---}$ \\
\hline
\end{tabular}

In the group of bacteria ascribed to the C. maltaromaticum, Lp.plantarum, and Lc. Lactis species, there was variability in some enzymatic activities; the positive strains percentage is highlighted in Table 2 using sparkline charts.

\section{Discussion}

Our results highlight that in the LAB community of the gut microbiota of the Mediterranean trout, there is a predominance of C. maltaromaticum and Lp. plantarum. There are no similar studies available on this freshwater fish for comparison. Diet and environmental temperature are among the factors that have the greatest impact on the gut bacterial communities of fishes [8-10,31,32]. Therefore, it is assumed that the protein-rich diet of the Mediterranean trout and the temperature of the water $\left(5-15^{\circ} \mathrm{C}\right)$ in which it lives also affects the composition of the intestinal LAB community [33]. The results obtained by Bucio et al. [13] in a study on the gut microbiota of 11 other freshwater fish species taken from rivers and fish farms highlighted the minor presence of $L p$. plantarum and the absence of C. maltaromaticum. Instead, other studies showed that C. maltaromaticum are important inhabitants of the gastrointestinal tract of freshwater and marine fishes [3,11,12,34-38]. This bacterium is capable of growing in harsh conditions, such as low temperature, low pressure, and anoxic conditions; moreover, it was found that the temperate/polar aquatic and terrestrial environments are both natural habitats [39].

Although a fish probiotic culture was used $[40,41]$, several cases of disease associated with C. maltaromaticum were reported [42-44]. However, a recent study showed that the bacterial virulence factor was present only in some strains derived from diseased fishes [45]. 
Lp. plantarum is a versatile and ubiquitous microorganism that is capable of colonizing several ecological niches, including the gastrointestinal tract of mammals, insects, and fishes $[3,46,47]$. Our results have shown that it is a predominant species in the community of LABs that populate the gut microbiota of S. macrostigma. Other studies have shown the presence of Lp. plantarum in the intestinal tract of other freshwater fish [48] and some strains are used as probiotics in aquaculture practices $[5,49,50]$. In our study, the Lc. lactis species was isolated amongst the LAB in the Mediterranean trout intestine, which is in agreement with other studies carried out on salmonids [3,51,52]. It has generally been reported that Lc. lactis strains are highly adaptable to different environments, including animal sources, dairy products, and silages [53]. Some researchers have hypothesized that because Lc. lactis is a LAB found in milk and milk derivatives, it may also be present in the disposal effluents of dairy factories that are released into the environment [54]. Nevertheless, its frequent isolation from the intestines of freshwater and marine fish in areas that are not close to dairy industries has caused this hypothesis to be abandoned [55-57]. Furthermore, the phenotypic diversity between Lc. lactis strains derived from fish intestines and Lc. lactis strains derived from milk derivatives were demonstrated [58,59]. Recently, some strains of Lc. lactis were selected and proposed as probiotics in the fish diet $[35,60]$.

The Enterococcus genus includes species that predominantly reside in the gastrointestinal tract of humans and animals; nonetheless, they are widely distributed in the environment [61,62]. The results of our survey have highlighted the presence of E. faecalis in the intestinal tract of $S$. macrostigma, confirming its frequent presence in the gut microbiota of fishes $[3,63]$. The E. faecalis are resilient and versatile species that are able to survive under harsh conditions [64]. Some strains of this species have been proposed as probiotics in aquaculture $[5,65]$.

Our results confirmed that, more or less frequently, some LABs belonging to the $V$. fluvialis, W. pseudomesenteroides, and L. acidophilus species can be isolated from fish guts $[3,12,51,66,67]$.

Bacteria present in the aquatic environment and introduced with food may influence the composition of the gut microbiota in fish [68].

LABs are ubiquitous microorganisms and several studies found the presence of species such as C. maltoaromaticum and Lp. plantarum in the aquatic environment $[69,70]$ and in the microbiota of insects $[47,71]$. The reasons as to why the presence of these LAB species are recurrent in the intestinal tracts of several fish species and the reasons for the mutual relationships with the host needs to be understood.

Our study was conducted using a culture-dependent method; further studies using culture-independent methods will be applied in the future (e.g., next-generation sequencing (NGS)) for the assessment of biodiversity in gut microbiota communities of wild Mediterranean trout. However, the technique we adopted allowed us to isolate the most numerically representative LABs from the intestinal tract of this salmonid and to submit them to a first characterization based on the in vitro evaluation of their enzymatic profile.

The environmental temperature and the host trophic levels (herbivorous, carnivorous, omnivorous) influenced the composition and metabolic capacity of the gut microbiota of wild freshwater fishes [33,72-74]. The gut microbiota plays a major role in the nutrition, growth, health, and survival of the host fish [75]. Specific bacteria composing the gut microbiota are involved in the breakdown of large food molecules (i.e., polysaccharides, proteins, fats, nucleic acids) [76].

The LABs are producers of extracellular enzymes that are involved in the breakdown of cellulose, starch, proteins, and lipids [77-80]. In our research, all C. maltoaromaticum strains displayed aminopeptidase activity (leucine, cystine, and valine arylamidase) as proteolytic indicators and the alkaline and acid phosphatase activities involved in lipidic metabolism $[81,82]$.

All the $C$. maltoaromaticum and Lp. plantarum strains showed $\mathrm{N}$-acetyl- $\beta$-glucosaminidase activity. LABs producing this enzyme could facilitate the breakdown of the exoskeleton of many invertebrates, including insects, which are the prey of the Mediterranean trout in 
its natural habitat [83]. The exoskeletons consist mainly of chitin, a linear polysaccharide composed of $\mathrm{N}$-acetylglucosamine subunits linked via $\beta-1,4$ bonds [84].

The lipase and $\alpha$-chymotrypsin activities were detected only in Lc. lactis strains. These data confirm the potential of this bacterial species in the breakdown of proteins and lipids [85]. In the group of bacteria ascribed to species C. maltaromaticum, Lp. plantarum, and Lc. lactis, there was variability in some enzymatic activities. However, the limited number of isolated LAB and the techniques used did not allow us to carry out a meaningful analysis on the intraspecific variability (phenotypic and genotypic). In the future, when our collection of bacteria is numerically more substantial, further studies on these important aspects will be carried out.

The characterization of microbial populations in the intestinal microenvironment of fish and understanding the physiological interactions between the indigenous microbiota and the host might have important implications.

However, the enzymatic properties of all the isolate strains shown in vitro did not axiomatically result in a positive contribution in digestive processes; this aspect deserves further investigation.

In contrast to endothermic animals, the exact role of gut microbiota in fish nutrition is difficult to conclude as a consequence of the complex and variable ecology of the GI tract of fish [86].

Moreover, among the microbial population in the fish gut, beneficial enzyme-producing bacteria continuously compete with pathogens through competitive exclusion; thus, this topic should be addressed in studies conducted in vitro and in vivo.

In general, the microbial population of the gut represents a very important and diversified enzymatic potential, and the enzymatic mass present in the digestive tract might interfere in a considerable way with a major part of the metabolism of the host animal $[4,72]$.

Furthermore, the role of enzyme-producing fish gut bacteria as probiotics in the enhancement of food digestibility and their effect on gut enzyme activity was evaluated through several investigations $[87,88]$.

Some studies have shown that the formation of the microbiota of the digestive tract from the larval stage to adult fish is formed gradually [89-92].

The enzyme-producing microorganisms isolated from fish digestive tracts can be beneficially used as a probiotic, especially in the larval stages [78]. The main strategy for using probiotics is to isolate intestinal bacteria with favorable properties from mature animals and include a large quantity of bacteria in the feed of immature animals of the same species $[87,93,94]$.

In this context, the search for beneficial extracellular enzyme-producing gut bacteria to be used as probiotics for the fish may be of interest. Most studies on enzyme-producing gut bacteria isolated from fish were conducted on different fish species, while few studies have been carried out on salmonids [77].

Therefore, we believe that the topic enzyme-producing LABs isolated from fish deserves further investigations, especially in relation to chitinase activity, as chitin is one of the most renewable biopolymers on earth and might be useful as a constitutive material in formulated fish feed in the future. Even though dietary chitin modulates the intestinal microbiota and influences disease resistance, susceptibility, and innate immune parameters, these topics are not fully understood; as a consequence, further studies are needed [95].

The environmental temperature and the host diet create strong selective pressure in the gut, which shapes the structure of the gut microbial community $[9,33,73,96]$. S. macrostigma is a cold stenothermal fish species, which, in the natural environment, has a diet that is almost exclusively carnivorous. Our results suggest that these factors are important in shaping the gut microbial community of these fish. The microbial communities that constitute fish microbiomes are essential for the host's health. Therefore, a better understanding of the natural bacterial communities of healthy individuals and how they interact with the host and other environmental factors is of crucial importance [97]. Captive animals tend to 
have different gut microbial communities compared with their wild counterparts $[15,54,98]$. The host-gut microbe mutualism evolved in a natural environment with complex climate patterns and food availability. A complete examination of host-intestine microbe dynamics must consider these factors [1]. This information would lay the foundations for exploring the impact of the gut microbiota composition and its function on the ecology, fitness, and evolution of their respective hosts. Discovering the core gut microbiome is crucial for understanding the ecology of microbial consortia and it is the first step toward defining a stable and healthy bacterial community in fish intestines. We believe that implementing the host-microbiota evolutionary process and microbial ecology into conservation policies would not only improve the efficiency of stocking programs for S. macrostigma but also for every fish species suffering a demographic decline [99].

The results obtained in this study show that the dominant LABs that are associated with the intestinal tract of the Mediterranean trout specimens examined belong to $C$. maltoaromaticum and Lp. plantarum species.

Our study is certainly not exhaustive and further genotypic and phenotypic investigations are underway on the gut microbiota of Mediterranean trout. These additional studies are needed to produce a greater understanding of the interactions between environmenthost-microbiota and how specific microbes, such as LABs, can be used as resources to improve the health and wellbeing of this fish $[81,82]$.

Supplementary Materials: The following are available online at https: / www.mdpi.com/article / $10.3390 /$ life11070667/s1. Table S1. List of the isolates LABs with corresponding GenBank (NCBI) accession numbers and the taxonomic references.

Author Contributions: Conceptualization, M.I. (Massimo Iorizzo) and M.D.; data curation, G.A., F.L. and M.I. (Massimo Iorizzo); formal analysis, M.I. (Mario Ianiro), G.A. and B.T.; funding acquisition, R.C. and M.S.; investigation, B.T. and P.T.; methodology, G.A. and B.T.; software, F.L.; supervision, R.C. and N.I.; validation, P.T. and M.S.; writing—original draft, M.I. (Massimo Iorizzo); writingreview and editing, M.I. (Massimo Iorizzo), G.A. and F.L. All authors have read and agreed to the published version of the manuscript.

Funding: This research received no external funding.

Acknowledgments: The authors thank Stefano Esposito (Mediterranean Trout Research Group, Research Center "I Giardini dell'Acqua," Collagna, Italy) for the technical support in fish sampling, which was provided during the scientific activities of the LIFE Nat. Sal. Mo Project (LIFE17 NAT/IT/000547), Project Manager: Nicolaia Iaffaldano (Department of Agricultural, Environmental and Food Sciences; University of Molise; Campobasso; Italy).

Conflicts of Interest: The authors declare no conflict of interest.

\section{References}

1. Tarnecki, A.; Burgos, F.; Ray, C.; Arias, C. Fish intestinal microbiome: Diversity and symbiosis unravelled by metagenomics. J. Appl. Microbiol. 2017, 123, 2-17. [CrossRef] [PubMed]

2. Wang, A.R.; Ran, C.; Ringø, E.; Zhou, Z.G. Progress in fish gastrointestinal microbiota research. Rev. Aquac. 2018, 10, 626-640. [CrossRef]

3. Ringø, E.; Hoseinifar, S.H.; Ghosh, K.; Van Doan, H.; Beck, B.R.; Song, S.K. Lactic Acid Bacteria in Finfish-An Update. Front. Microbiol. 2018, 9, 1818. [CrossRef]

4. Butt, R.L.; Volkoff, H. Gut Microbiota and Energy Homeostasis in Fish. Front. Endocrinol. 2019, 10, 9. [CrossRef] [PubMed]

5. Ringø, E.; Van Doan, H.; Lee, S.H.; Soltani, M.; Hoseinifar, S.H.; Harikrishnan, R.; Song, S.K. Probiotics, lactic acid bacteria and bacilli: Interesting supplementation for aquaculture. J. Appl. Microbiol. 2020, 129, 116-136. [CrossRef] [PubMed]

6. Pessione, E. Lactic acid bacteria contribution to gut microbiota complexity: Lights and shadows. Front. Cell. Infect. Microbiol. 2012, 2, 86. [CrossRef] [PubMed]

7. Merrifield, D.L.; Balcázar, J.L.; Daniels, C.; Zhou, Z.; Carnevali, O.; Sun, Y.-Z.; Hoseinifar, S.H.; Ringø, E. Indigenous Lactic Acid Bacteria in Fish and Crustaceans. Aquac. Nutr. Gut Health Probiotics Prebiotics 2014, 128-168. [CrossRef]

8. Sullam, K.E.; Essinger, S.D.; Lozupone, C.A.; O'Connor, M.P.; Rosen, G.L.; Knight, R.; Kilham, S.S.; Russell, J.A. Environmental and ecological factors that shape the gut bacterial communities of fish: A meta-analysis. Mol. Ecol. 2012, 21, 3363-3378. [CrossRef] 
9. Ringo, E.; Zhou, Z.; Vecino, J.L.G.; Wadsworth, S.; Romero, J.P.; Krogdahl, A.; Olsen, R.; Dimitroglou, A.; Foey, A.; Davies, S.G.; et al. Effect of dietary components on the gut microbiota of aquatic animals. A never-ending story? Aquac. Nutr. 2015, 22, 219-282. [CrossRef]

10. Pedrotti, F.S.; Davies, S.; Merrifield, D.; Marques, M.R.F.; Fraga, A.P.M.; Mouriño, J.L.P.; Fracalossi, D.M. The autochthonous microbiota of the freshwater omnivores jundiá (Rhamdia quelen) and tilapia (Oreochromis niloticus) and the effect of dietary carbohydrates. Aquac. Res. 2015, 46, 472-481. [CrossRef]

11. González, C.-J.; López-Díaz, T.-M.; García-López, M.-L.; Prieto, M.; Otero, A. Bacterial Microflora of Wild Brown Trout (Salmo trutta), Wild Pike (Esox lucius), and Aquacultured Rainbow Trout (Oncorhynchus mykiss). J. Food Prot. 1999, 62, $1270-1277$. [CrossRef]

12. González, C.; Encinas, J.; García-López, M.; Otero, A. Characterization and identification of lactic acid bacteria from freshwater fishes. Food Microbiol. 2000, 17, 383-391. [CrossRef]

13. Bucio, A.; Hartemink, R.; Schrama, J.W.; Verreth, J.; Rombouts, F.M. Presence of lactobacilli in the intestinal content of freshwater fish from a river and from a farm with a recirculation system. Food Microbiol. 2006, 23, 476-482. [CrossRef] [PubMed]

14. Skrodenyte-Arbaciauskiene, V.; Sruoga, A.; Butkauskas, D. Assessment of microbial diversity in the river trout Salmo trutta fario L. intestinal tract identified by partial 16S rRNA gene sequence analysis. Fish. Sci. 2006, 72, 597-602. [CrossRef]

15. Amato, K. Co-evolution in context: The importance of studying gut microbiomes in wild animals. Microbiome Sci. Med. 2013, 1, 1. [CrossRef]

16. Directive, H. Council Directive 92/43/EEC of 21 May 1992 on the Conservation of Natural Habitats and of Wild Fauna and Flora. Off. J. Eur. Union 1992, 206, 7-50.

17. Réalis-Doyelle, E.; Pasquet, A.; De Charleroy, D.; Fontaine, P.; Teletchea, F. Strong Effects of Temperature on the Early Life Stages of a Cold Stenothermal Fish Species, Brown Trout (Salmo trutta L.). PLoS ONE 2016, 11, e0155487. [CrossRef] [PubMed]

18. Ojanguren, A.; Braña, F. Thermal dependence of embryonic growth and development in brown trout. J. Fish Biol. 2003, 62, 580-590. [CrossRef]

19. Réalis-Doyelle, E.; Gisbert, E.; Alcaraz, C.; Teletchea, F.; Pasquet, A. Temperature affects growth allometry and development patterns in brown trout (Salmo trutta) fry: A multitrait approach. Can. J. Fish. Aquat. Sci. 2018, 75, 714-722. [CrossRef]

20. Almodóvar, A.; Nicola, G.G.; Ayllón, D.; Elvira, B. Global warming threatens the persistence of Mediterranean brown trout. Glob. Chang. Biol. 2012, 18, 1549-1560. [CrossRef]

21. Powers, E.M. Efficacy of the Ryu nonstaining $\mathrm{KOH}$ technique for rapidly determining gram reactions of food-borne and waterborne bacteria and yeasts. Appl. Environ. Microbiol. 1995, 61, 3756-3758. [CrossRef]

22. Muyzer, G.; de Waal, E.C.; Uitterlinden, A.G. Profiling of complex microbial populations by denaturing gradient gel electrophoresis analysis of polymerase chain reaction-amplified genes coding for 16S rRNA. Appl. Environ. Microbiol. 1993, 59, 695-700. [CrossRef] [PubMed]

23. Hou, Q.; Bai, X.; Li, W.; Gao, X.; Zhang, F.; Sun, Z.; Zhang, H. Design of Primers for Evaluation of Lactic Acid Bacteria Populations in Complex Biological Samples. Front. Microbiol. 2018, 9, 2045. [CrossRef]

24. Zhang, Z.; Schwartz, S.; Wagner, L.; Miller, W. A Greedy Algorithm for Aligning DNA Sequences. J. Comput. Biol. 2000, 7, 203-214. [CrossRef]

25. NCBI Resource Coordinators. Database resources of the National Center for Biotechnology Information. Nucleic Acids Res. 2018, 46, D8-D13. [CrossRef] [PubMed]

26. Johnson, J.S.; Spakowicz, D.J.; Hong, B.-Y.; Petersen, L.M.; Demkowicz, P.; Chen, L.; Leopold, S.R.; Hanson, B.M.; Agresta, H.O.; Gerstein, M.; et al. Evaluation of $16 \mathrm{~S}$ rRNA gene sequencing for species and strain-level microbiome analysis. Nat. Commun. 2019, 10, 5029. [CrossRef]

27. Kumar, S.; Stecher, G.; Li, M.; Knyaz, C.; Tamura, K. MEGA X: Molecular evolutionary genetics analysis across computing platforms. Mol. Biol. Evol. 2018, 35, 1547-1549. [CrossRef]

28. Hasegawa, M.; Kishino, H.; Yano, T.-A. Dating of the human-ape splitting by a molecular clock of mitochondrial DNA. J. Mol. Evol. 1985, 22, 160-174. [CrossRef]

29. Fei, Y.-T.; Liu, D.-M.; Luo, T.-H.; Chen, G.; Wu, H.; Li, L.; Yu, Y.-G. Molecular Characterization of Lactobacillus plantarum DMDL 9010, a Strain with Efficient Nitrite Degradation Capacity. PLoS ONE 2014, 9, e113792. [CrossRef]

30. Torriani, S.; Felis, G.E.; Dellaglio, F. Differentiation of Lactobacillus plantarum, L. pentosus, and L. paraplantarum by recA Gene Sequence Analysis and Multiplex PCR Assay with recA Gene-Derived Primers. Appl. Environ. Microbiol. 2001, 67, 3450-3454. [CrossRef] [PubMed]

31. Wong, S.; Rawls, J.F. Intestinal microbiota composition in fishes is influenced by host ecology and environment. Mol. Ecol. 2012, 21, 3100-3102. [CrossRef] [PubMed]

32. Kashinskaya, E.; Simonov, E.; Kabilov, M.; Izvekova, G.; Andree, K.; Solovyev, M. Diet and other environmental factors shape the bacterial communities of fish gut in an eutrophic lake. J. Appl. Microbiol. 2018, 125, 1626-1641. [CrossRef] [PubMed]

33. Ingerslev, H.-C.; von Gersdorff Jørgensen, L.; Strube, M.L.; Larsen, N.; Dalsgaard, I.; Boye, M.; Madsen, L. The development of the gut microbiota in rainbow trout (Oncorhynchus mykiss) is affected by first feeding and diet type. Aquaculture 2014, 424-425, 24-34. [CrossRef]

34. Huyben, D.; Sun, L.; Moccia, R.; Kiessling, A.; Dicksved, J.; Lundh, T. Dietary live yeast and increased water temperature influence the gut microbiota of rainbow trout. J. Appl. Microbiol. 2018, 124, 1377-1392. [CrossRef] [PubMed] 
35. Araújo, C.; Muñoz-Atienza, E.; Nahuelquin, Y.; Poeta, P.; Igrejas, G.; Hernández, P.E.; Herranz, C.; Cintas, L.M. Inhibition of fish pathogens by the microbiota from rainbow trout (Oncorhynchus mykiss, Walbaum) and rearing environment. Anaerobe 2015, 32, 7-14. [CrossRef]

36. Balcázar, J.L.; de Blas, I.; Ruiz-Zarzuela, I.; Vendrell, D.; Gironés, O.; Muzquiz, J.L. Sequencing of variable regions of the 16S rRNA gene for identification of lactic acid bacteria isolated from the intestinal microbiota of healthy salmonids. Comp. Immunol. Microbiol. Infect. Dis. 2007, 30, 111-118. [CrossRef]

37. Ringo, E.; Bendiksen, H.; Wesmajervi, M.; Olsen, R.; Jansen, P.; Mikkelsen, H. Lactic acid bacteria associated with the digestive tract of Atlantic salmon (Salmo salar L.). J. Appl. Microbiol. 2000, 89, 317-322. [CrossRef]

38. Ringø, E.; Wesmajervi, M.S.; Bendiksen, H.R.; Berg, A.; Olsen, R.E.; Johnsen, T.; Mikkelsen, H.; Seppola, M.; Strøm, E.; Holzapfel, W. Identification and Characterization of Carnobacteria Isolated from Fish Intestine. Syst. Appl. Microbiol. 2001, 24, 183-191. [CrossRef]

39. Nicholson, W.L.; Krivushin, K.; Gilichinsky, D.; Schuerger, A.C. Growth of Carnobacterium spp. from permafrost under low pressure, temperature, and anoxic atmosphere has implications for Earth microbes on Mars. Proc. Natl. Acad. Sci. USA 2013, 110, 666-671. [CrossRef]

40. Kim, D.-H.; Austin, B. Characterization of probiotic carnobacteria isolated from rainbow trout (Oncorhynchus mykiss) intestine. Lett. Appl. Microbiol. 2008, 47, 141-147. [CrossRef]

41. Leisner, J.J.; Laursen, B.G.; Prévost, H.; Drider, D.; Dalgaard, P. Carnobacterium:positive and negative effects in the environment and in foods. FEMS Microbiol. Rev. 2007, 31, 592-613. [CrossRef]

42. Schaffer, P.A.; Lifland, B.; Van Sommeran, S.; Casper, D.R.; Davis, C.R. Meningoencephalitis Associated with Carnobacterium maltaromaticum-Like Bacteria in Stranded Juvenile Salmon Sharks (Lamna ditropis). Vet. Pathol. 2013, 50, 412-417. [CrossRef]

43. Loch, T.P.; Xu, W.; Fitzgerald, S.M.; Faisal, M. Isolation of a Carnobacterium maltaromaticum-like bacterium from systemically infected lake whitefish (Coregonus clupeaformis). FEMS Microbiol. Lett. 2008, 288, 76-84. [CrossRef]

44. Pastorino, P.; Colussi, S.; Pizzul, E.; Varello, K.; Menconi, V.; Mugetti, D.; Tomasoni, M.; Esposito, G.; Bertoli, M.; Bozzetta, E.; et al. The unusual isolation of carnobacteria in eyes of healthy salmonids in high-mountain lakes. Sci. Rep. 2021, 11, 1-10. [CrossRef] [PubMed]

45. Roh, H.; Kim, B.S.; Lee, M.K.; Park, C.; Kim, D. Genome-wide comparison of Carnobacterium maltaromaticum derived from diseased fish harbouring important virulence-related genes. J. Fish Dis. 2020, 43, 1029-1037. [CrossRef] [PubMed]

46. Siezen, R.J.; Tzeneva, V.A.; Castioni, A.; Wels, M.; Phan, H.T.K.; Rademaker, J.L.; Starrenburg, M.J.C.; Kleerebezem, M.; Molenaar, D.; Vlieg, J.E.T.V.H. Phenotypic and genomic diversity ofLactobacillus plantarumstrains isolated from various environmental niches. Environ. Microbiol. 2010, 12, 758-773. [CrossRef]

47. Iorizzo, M.; Pannella, G.; Lombardi, S.J.; Ganassi, S.; Testa, B.; Succi, M.; Sorrentino, E.; Petrarca, S.; De Cristofaro, A.; Coppola, R.; et al. Inter- and Intra-Species Diversity of Lactic Acid Bacteria in Apis mellifera ligustica Colonies. Microorganisms 2020, 8, 1578. [CrossRef]

48. Maji, U.J.; Mohanty, S. Genotypic characterization of Lactic acid bacteria in gut microbiome of freshwater fish. Microbiology 2017, 86, 276-285. [CrossRef]

49. Mohamad, N.; Manan, H.; Sallehhuddin, M.; Musa, N.; Ikhwanuddin, M. Screening of Lactic Acid Bacteria isolated from giant freshwater prawn (Macrobrachium rosenbergii) as potential probiotics. Aquac. Rep. 2020, 18, 100523. [CrossRef]

50. Foysal, J.; Fotedar, R.; Siddik, M.A.B.; Tay, A. Lactobacillus acidophilus and L. plantarum improve health status, modulate gut microbiota and innate immune response of marron (Cherax cainii). Sci. Rep. 2020, 10, 1-13. [CrossRef] [PubMed]

51. Michel, C.; Pelletier, C.; Boussaha, M.; Douet, D.-G.; Lautraite, A.; Tailliez, P. Diversity of Lactic Acid Bacteria Associated with Fish and the Fish Farm Environment, Established by Amplified rRNA Gene Restriction Analysis. Appl. Environ. Microbiol. 2007, 73, 2947-2955. [CrossRef] [PubMed]

52. Didinen, B.; Onuk, E.; Metin, S.; Cayli, O. Identification and characterization of lactic acid bacteria isolated from rainbow trout (Oncorhynchus mykiss, Walbaum 1792), with inhibitory activity against Vagococcus salmoninarum and Lactococcus garvieae. Aquac. Nutr. 2018, 24, 400-407. [CrossRef]

53. Kelly, W.; Ward, L. Genotypic vs. phenotypic biodiversity in Lactococcus lactis. Microbiology 2002, 148, 3332-3333. [CrossRef] [PubMed]

54. Ghanbari, M.; Rezaei, M.; Jami, M.; Nazari, R. Isolation and Characterization of Lactobacillus Species from Intestinal Contents of Beluga (Huso Huso) and Persian Sturgeon (Acipenser Persicus). Iran. J. Vet. Res. 2009, 10, 152-157. [CrossRef]

55. Hagi, T.; Tanaka, D.; Iwamura, Y.; Hoshino, T. Diversity and seasonal changes in lactic acid bacteria in the intestinal tract of cultured freshwater fish. Aquaculture 2004, 234, 335-346. [CrossRef]

56. Ghiasi, F. Predominant lactic acid bacteria isolated from the intestines of silver carp in low water temperature. Afr. J. Biotechnol. 2011, 10, 12717-12721. [CrossRef]

57. Itoi, S.; Abe, T.; Washio, S.; Ikuno, E.; Kanomata, Y.; Sugita, H. Isolation of halotolerant Lactococcus lactis subsp. lactis from intestinal tract of coastal fish. Int. J. Food Microbiol. 2008, 121, 116-121. [CrossRef]

58. Itoi, S.; Yuasa, K.; Washio, S.; Abe, T.; Ikuno, E.; Sugita, H. Phenotypic variation inLactococcus lactissubsp.lactisisolates derived from intestinal tracts of marine and freshwater fish. J. Appl. Microbiol. 2009, 107, 867-874. [CrossRef] 
59. Rademaker, J.L.W.; Herbet, H.; Starrenburg, M.J.C.; Naser, S.M.; Gevers, D.; Kelly, W.J.; Hugenholtz, J.; Swings, J.; Van Hylckama Vlieg, J.E.T. Diversity Analysis of Dairy and Nondairy Lactococcus lactis Isolates, Using a Novel Multilocus Sequence Analysis Scheme and (GTG) 5 -PCR Fingerprinting. Appl. Environ. Microbiol. 2007, 73, 7128-7137. [CrossRef]

60. Mortezaei, F.; Royan, M.; Noveirian, H.A.; Babakhani, A.; KordGhashlaghi, H.A.; Balcázar, J. In vitro assessment of potential probiotic characteristics of indigenous Lactococcus lactis and Weissella oryzae isolates from rainbow trout (Oncorhynchus mykiss Walbaum). J. Appl. Microbiol. 2020, 129, 1004-1019. [CrossRef] [PubMed]

61. Devriese, L.A.; Van De Kerckhove, A.; Kilpper-Balz, R.; Schleifer, K.H. Characterization and Identification of Enterococcus Species Isolated from the Intestines of Animals. Int. J. Syst. Evol. Microbiol. 1987, 37, 257-259. [CrossRef]

62. Dubin, K.; Pamer, E.G. Enterococci and Their Interactions with the Intestinal Microbiome. Microbiol. Spectr. 2017, 5. [CrossRef] [PubMed]

63. Cai, Y.; Suyanandana, P.; Saman, P.; Benno, Y. Classification and characterization of lactic acid bacteria isolated from the intestines of common carp and freshwater prawns. J. Gen. Appl. Microbiol. 1999, 45, 177-184. [CrossRef] [PubMed]

64. García-Solache, M.; Rice, L.B. The Enterococcus: A Model of Adaptability to Its Environment. Clin. Microbiol. Rev. 2019, 32, e00058-18. [CrossRef]

65. Sica, M.G.; Brugnoni, L.I.; Marucci, P.L.; Cubitto, M.A. Characterization of probiotic properties of lactic acid bacteria isolated from an estuarine environment for application in rainbow trout (Oncorhynchus mykiss, Walbaum) farming. Antonie van Leeuwenhoek 2012, 101, 869-879. [CrossRef]

66. Román, L.; Real, F.; Sorroza, L.; Padilla, D.; Acosta, B.; Grasso, V.; Bravo, J.; Acosta, F. The in vitro effect of probiotic Vagococcus fluvialis on the innate immune parameters of Sparus aurata and Dicentrarchus labrax. Fish Shellfish Immunol. 2012, 33, 1071-1075. [CrossRef] [PubMed]

67. Lyons, P.P.; Turnbull, J.; Dawson, K.A.; Crumlish, M. Exploring the microbial diversity of the distal intestinal lumen and mucosa of farmed rainbow troutOncorhynchus mykiss(Walbaum) using next generation sequencing (NGS). Aquac. Res. 2017, 48, 77-91. [CrossRef]

68. Zeng, A.; Tan, K.; Gong, P.; Lei, P.; Guo, Z.; Wang, S.; Gao, S.; Zhou, Y.; Shu, Y.; Zhou, X.; et al. Correlation of microbiota in the gut of fish species and water. 3 Biotech 2020, 73, 7128-7137. [CrossRef]

69. Lauzon, H.L.; Ringø, E. Prevalence and Application of Lactic Acid Bacteria in Aquatic Environments. In Lactic Acid Bacteria, 4th ed.; CRC Press: Boca Raton, FL, USA, 2012; pp. 593-631.

70. George, F.; Daniel, C.; Thomas, M.; Singer, E.; Guilbaud, A.; Tessier, F.J.; Revol-Junelles, A.-M.; Borges, F.; Foligné, B. Occurrence and Dynamism of Lactic Acid Bacteria in Distinct Ecological Niches: A Multifaceted Functional Health Perspective. Front. Microbiol. 2018, 9, 2899. [CrossRef]

71. Shannon, A.; Attwood, G.; Hopcroft, D.; Christeller, J. Characterization of lactic acid bacteria in the larval midgut of the keratinophagous lepidopteran, Hofmannophila pseudospretella. Lett. Appl. Microbiol. 2008, 32, 36-41. [CrossRef]

72. Liu, H.; Guo, X.; Gooneratne, S.R.; Lai, R.; Zeng, C.; Zhan, F.; Wang, W. The gut microbiome and degradation enzyme activity of wild freshwater fishes influenced by their trophic levels. Sci. Rep. 2016, 6, 24340. [CrossRef]

73. Sepulveda, J.; Moeller, A.H. The Effects of Temperature on Animal Gut Microbiomes. Front. Microbiol. 2020, 11, 384. [CrossRef]

74. Zarkasi, K.Z.; Taylor, R.; Abell, G.C.J.; Tamplin, M.L.; Glencross, B.D.; Bowman, J. Atlantic Salmon (Salmo salar L.) Gastrointestinal Microbial Community Dynamics in Relation to Digesta Properties and Diet. Microb. Ecol. 2016, 71, 589-603. [CrossRef]

75. Banerjee, G.; Ray, A.K. Bacterial symbiosis in the fish gut and its role in health and metabolism. Symbiosis 2017, 72, 1-11. [CrossRef]

76. Tremaroli, V.; Bäckhed, F. Functional interactions between the gut microbiota and host metabolism. Nature 2012, 489, 242-249. [CrossRef] [PubMed]

77. Ray, A.; Ghosh, K.; Ringø, E. Enzyme-producing bacteria isolated from fish gut: A review. Aquac. Nutr. 2012, 18, 465-492 [CrossRef]

78. Bairagi, A.; Ghosh, K.S.; Sen, S.K.; Ray, A.K. Enzyme producing bacterial flora isolated from fish digestive tracts. Aquac. Int. 2002, 10, 109-121. [CrossRef]

79. Mohammadian, T.; Alishahi, M.; Tabande, M.R.; Ali, Z.D.; Nejad, A.J. Effect of Different Levels of Lactobacillus Casei on Growth Performance and Digestive Enzymes Activity of Shirbot (Barbus Gryprus). J. Vet. Res. 2017, 72, 43-52.

80. Raftari, M.; Ghafourian, S.; Bakar, F.A. Metabolic engineering ofLactococcus lactisinfluence of the overproduction of lipase enzyme. J. Dairy Res. 2013, 80, 490-495. [CrossRef]

81. Hernández-Mosqueira, C.; Velez-Delvalle, C.; Kuri-Harcuch, W. Tissue alkaline phosphatase is involved in lipid metabolism and gene expression and secretion of adipokines in adipocytes. Biochim. Biophys. Acta 2015, 1850, 2485-2496. [CrossRef] [PubMed]

82. Mir, I.H.; Channa, A. Histochemical Distribution of Lipase and Acid Phosphatase in the Intestinal Tract of the Snow Trout, Schizothorax curvifrons Heckel. J. Biol. Sci. 2010, 10, 643-647. [CrossRef]

83. Leisner, J.J.; Vogensen, F.K.; Kollmann, J.; Aideh, B.; Vandamme, P.; Vancanneyt, M.; Ingmer, H. $\alpha$-Chitinase activity among lactic acid bacteria. Syst. Appl. Microbiol. 2008, 31, 151-156. [CrossRef] [PubMed]

84. Moussian, B. Chitin: Structure, Chemistry and Biology. In Targeting Chitin-Containing Organisms; Yang, Q., Fukamizo, T., Eds.; Springer: Singapore, 2019; pp. 5-18. ISBN 9789811373183.

85. García-Cano, I.; Rocha-Mendoza, D.; Ortega-Anaya, J.; Wang, K.; Kosmerl, E.; Jiménez-Flores, R. Lactic acid bacteria isolated from dairy products as potential producers of lipolytic, proteolytic and antibacterial proteins. Appl. Microbiol. Biotechnol. 2019, 103, 5243-5257. [CrossRef] 
86. Nayak, S.K. Role of gastrointestinal microbiota in fish. Aquac. Res. 2010, 41, 1553-1573. [CrossRef]

87. Ganguly, S.; Paul, I.; Mukhopadhayay, S. Immunostimulant, Probiotic and Prebiotic-Their Applications and Effectiveness in Aquaculture: A Review. Isr. J. Aquacult. Bamid. 2010, 62, 130-138.

88. Das, P.; Mandal, S.; Khan, A.; Manna, S.K.; Ghosh, K. Distribution of extracellular enzyme-producing bacteria in the digestive tracts of 4 brackish water fish species. Turk. J. Zool. 2014, 38, 79-88. [CrossRef]

89. Michl, S.C.; Beyer, M.; Ratten, J.-M.; Hasler, M.; Laroche, J.; Schulz, C. A diet-change modulates the previously established bacterial gut community in juvenile brown trout (Salmo trutta). Sci. Rep. 2019, 9, 2339. [CrossRef]

90. Stephens, W.Z.; Burns, A.R.; Stagaman, K.; Wong, S.; Rawls, J.; Guillemin, K.; Bohannan, B.J.M. The composition of the zebrafish intestinal microbial community varies across development. ISME J. 2016, 10, 644-654. [CrossRef] [PubMed]

91. Yan, Q.; Li, J.; Yu, Y.; Wang, J.; He, Z.; Van Nostrand, J.D.; Kempher, M.L.; Wu, L.; Wang, Y.; Liao, L.; et al. Environmental filtering decreases with fish development for the assembly of gut microbiota. Environ. Microbiol. 2016, 18, 4739-4754. [CrossRef]

92. Wang, W.; Wu, S.; Zheng, Y.; Cheng, Y.; Li, W.; Zou, H.; Wang, G. Characterization of the bacterial community associated with early-developmental stages of grass carp (Ctenopharyngodon idella). Aquac. Res. 2015, 46, 2728-2735. [CrossRef]

93. Gildberg, A.; Mikkelsen, H.; Sandaker, E.; Ringø, E. Probiotic effect of lactic acid bacteria in the feed on growth and survival of fry of Atlantic cod (Gadus morhua). Hydrobiologia 1997, 352, 279-285. [CrossRef]

94. Alonso-Fernández, S.; Castro, M.C.; Berdasco, M.; De La Banda, I.G.; Moreno-Ventas, X.; De Rojas, A.H. Isolation and Partial Characterization of Lactic Acid Bacteria from the Gut Microbiota of Marine Fishes for Potential Application as Probiotics in Aquaculture. Probiotics Antimicrob. Proteins 2018, 11, 569-579. [CrossRef]

95. Ringø, E.; Zhou, Z.; Olsen, R.; Song, S. Use of chitin and krill in aquaculture-The effect on gut microbiota and the immune system: A review. Aquac. Nutr. 2012, 18, 117-131. [CrossRef]

96. Dehler, C.E.; Secombes, C.J.; Martin, S.A. Environmental and physiological factors shape the gut microbiota of Atlantic salmon parr (Salmo salar L.). Aquaculture 2017, 467, 149-157. [CrossRef]

97. Boutin, S.; Bernatchez, L.; Audet, C.; Derôme, N. Network Analysis Highlights Complex Interactions between Pathogen, Host and Commensal Microbiota. PLoS ONE 2013, 8, e84772. [CrossRef]

98. Tan, C.K.; Natrah, I.; Suyub, I.B.; Edward, M.J.; Kaman, N.; Samsudin, A.A. Comparative study of gut microbiota in wild and captive Malaysian Mahseer (Tor tambroides). MicrobiologyOpen 2019, 8, e00734. [CrossRef] [PubMed]

99. Lavoie, C.; Courcelle, M.; Redivo, B.; Derome, N. Structural and compositional mismatch between captive and wild Atlantic salmon (Salmo salar) parrs' gut microbiota highlights the relevance of integrating molecular ecology for management and conservation methods. Evol. Appl. 2018, 11, 1671-1685. [CrossRef] 